\title{
Entrevista com Heleieth Saffioti
}

\author{
Juliana Cavilha Mendes \\ Universidade Federal do Rio Grande do Sul \\ Simone Becker \\ Universidade Federal da Grande Dourados
}

\section{Parte I - Trajetória de uma feminista}

Juliana Cavilha Mendes: Ao iniciar esta entrevista, gostaríamos que você falasse sobre sua formação educacional e sobre a relação dessa trajetória com o feminismo.

Heleieth Saffioti: Nunca identifiquei um momento, em minha vida, no qual eu pudesse dizer: "foi nesse, especificamente, que me tornei feminista". Desde criança, fui muito rebelde. Tenho um irmão e minha mãe dizia: "nesta família, os sexos vieram trocados, seu irmão é caseiro, é obediente, quando vou bater nele, ele não corre! Agora, você não, você é rueira!". Gostava de andar a cavalo e, quando tinha seis anos, meus pais se mudaram para o sertão, levando meu irmão, que tinha quatro anos e meio. Foram para uma cidade que se chama Auriflama, no Estado de São Paulo. Eu já era alfabetizada e estava na escola, por isso fiquei com meus avós, em Ibirá, no interior do mesmo Estado. Em toda minha época de estudante - exceto quando fiz Direito, curso no qual me formei com quase 50 anos - a escola pública era excelente.

Terminei $\circ 4^{\circ}$ ano primário e fui para o sertão, onde estavam meus pais. Lá havia apenas escola isolada até o terceiro ano, não havia grupo escolar, mas minha mãe, que tinha pouco estudo, sempre foi muito inteligente e perspicaz. Então, como era amiga de todas as professoras, solicitou que elas me permitissem atuar como monitora nas aulas, para que eu não me esquecesse do que havia aprendido. Não me esqueci de nada. Assim, nesse importante "cargo", fiquei lá três anos, porque minha família não tinha condições financeiras para me mandar estudar em outra cidade. Até que, com quase 13 anos, fui para a casa de uma tia, em Avaré, também no interior de São Paulo, que era casada, mas não tinha filhos. Acontece que ela ficou doente, um mês depois de eu ir morar com ela. Como não ficava bem permanecer sozinha com o marido dela, levaram-me para ltapetininga, onde eu tinha outro tio paterno, que era professor na Escola Agrícola. 
Mais adiante, estudei o abuso incestuoso, tendo aprendido que, muitas vezes, "o inimigo mora em casa". Hoje, conhecendo esse sério problema, vinculo a atitude de minhas tias paternas, de não me deixarem em Avaré, com o marido de minha tia, à maior experiência delas, se comparada à minha. Tão logo cheguei à fazenda em que ficava a escola em que meu tio paterno lecionava, a condução que fazia o trajeto fazenda-cidade foi desativada, não havendo, portanto, como morar lá e frequentar o ginásio, na cidade. Afinal, como iria eu para a cidade, estudar? Então, fui para a casa dos sogros desse meu tio. Foi uma fase muito feliz de minha vida. Dona Henriqueta e o Sr. Frank, que era alemão, eram protestantes, tinham duas filhas, uma delas se chamava lolanda e tinha quase a minha idade; a outra se convertera em minha tia, quando se casou com meu tio. Fiquei um ano em ltapetininga, cidade na qual realizei o primeiro ano do curso ginasial, entre os 13 e os 14 anos.

Depois, vim para São Paulo, antes de completar 14 anos, morar com duas tias solteiras e mais dois primos, irmãos entre si, a fim de estudar na famosa Escola Normal da Praça, ou seja, o Instituto de Educação "Caetano de Campos", que passara, a partir daquele ano, 1944, a oferecer aulas no período noturno. Eu fazia todo o trabalho da casa, estudava à noite, chegava de volta a casa, sozinha, após a meia noite. Tinha que descer uma ladeira, e quantas não foram as vezes em que a desci voando, porque me haviam assediado no ônibus. Uma moça de 14 anos, embora de uniforme, era considerada uma menina sozinha. Então, colocavam a mão na minha perna, simulavam esbarrar em meus seios. Era um "assédio sexual" bastante ameaçador para quem enfrentava, pela primeira vez, a grande cidade. Alguns desses homens chegavam a descer do ônibus e ir atrás de mim.

Eu aguentei um ano. Enfim, esse tipo de conduta não me agradava, tolhia minha liberdade e me infundia medo. Até hoje, não gosto de países muito machistas, como o México, tão lindo quanto sexista, cujos homens têm uma cantada grosseira, não porque não possa revidar a elas, mas porque isso tolhe minha liberdade. Tenho algumas experiências de países muçulmanos. No Marrocos, onde estive com meu marido, nada de desagradável ocorreu. Afinal, eu tinha um macho ao meu lado! E é isso que me deixa furiosa! Não poder exercer livremente meu direito de ir e vir. Mas, no Egito, país no qual estive sozinha, foi bem pior que no México. Basta ter a pele clara como a minha e usar roupas ocidentais, para se ter problema desse tipo, na rua. Disse que lá foi bem pior que no México, e foi mesmo, porque eles me tocavam. Havia desdobrado minha passagem para conhecer, pelo menos, um pouco de Istambul, que tanto me fascinava, e entrei em dúvida, ainda no Cairo, se deveria ou não ir. Pensava: os turcos não são árabes, mas são muçulmanos; logo, terei os mesmos problemas que enfrento aqui. Ocorre que tomo tudo como desafio, tendo decidido ir a Istambul. Foi maravilhoso! Nunca me aborreceram. De outra parte, sou vítima tanto do racismo francês contra negros, quanto desses últimos na medida em que me tomam por europeia ou norte-americana, 
sempre procurando encrenca. Uma vez, desci as escadarias da Igreja du Sacré Coeur a galope, pois havia sido seguida por um imenso negro, durante todo meu passeio pela igreja e seus arredores, onde fica o tentador Marché Saint Pierre.

Meu pai tinha uma chácara, em Auriflama, que não soube administrar, tendo-a vendido a preço de banana a um de seus irmãos. Este era padrinho de meu irmão e o mandou estudar, na idade certa, num colégio com internato. Eu não tive um padrinho desses. Quando se havia passado um ano que eu estava com estas tias-bruxas, decidi sair. Minhas duas avós tiveram, cada uma, 14 filhos. Imaginem vocês como diminuiu a fecundidade da mulher no espaço de duas gerações! Tinha um afeto muito profundo por minha avó materna e usufruía da condição de sua neta querida, com quem eu morara durante três anos e meio, tivera sete filhas e sete filhos. Destes últimos, só resta um, que é solitário há muitas décadas. Até uns 15 anos atrás, todas as mulheres estavam vivas. Deve mesmo ser verdade que o cromossomo Y já perdeu pedaços, já não guarda sua forma original nem seu poder. Anda bastante fraquinho e o prognóstico de alguns cientistas é de que ele venha a desaparecer. Felizmente, esses processos são muito lentos e nós não estaremos mais aqui, pois uma sociedade só de mulheres deve ser de uma chatice infinita! Disse a minha mãe que não mais ficaria em casa daquelas tias-bruxas, mas já havia falado com uma de suas irmãs, tia Maria, e que ela me aceitara como mais um membro da família, vivendo naquele pequeno domicílio. Ela teve um casal de filhos: Wilson e Vilma, aos quais quero muito, tendo esta minha prima como a irmã que não tive. Somos, até hoje, muito amigas. Vivi três anos com tia Maria, tio Sebastião e meus primos. Isto é, dos 15 aos 18 anos, quando meus pais e meu irmão se mudaram para São Paulo.

Casei-me com 22 anos, em 1956, pois nasci em 1934. No ano passado, 2004, fiz 70 anos. Foi minha primeira festa de aniversário, depois de adulta. Minha mãe teve sua grande festa, em 2003, quando completou 90 anos. Fiz questão de lhe oferecer essa festa, convidando todos os membros da família, inclusive os mais longínquos, ou seja, aqueles que só encontramos em velórios e enterros. Acho que minha mãe, uma guerreira, nunca havia tido tão linda festa de aniversário! Transbordava de alegria e eu, ao vê-la, também. Ela sempre teve uma personalidade forte, nunca dependeu de meu pai, que era a pessoa que me fazia carinho, na medida em que trabalhava quando queria. Ao contrário dele, minha mãe era a provedora, era a disciplinadora. Provavelmente, eu a tomei como modelo. Acontece que sou dura apenas na aparência. É só tirar a casquinha e verão uma mulher ultrassensível, uma mãezona, com aquele coração no qual sempre cabe mais um.

JC: E na continuidade, o que aconteceu? Quais as razões da escolha pelo curso de Ciências Sociais? Você já estava em São Paulo quando fez essa escolha? 
HS: Fiz o ginásio no Instituto de Educação "Caetano de Campos", este prédio aqui em frente do meu, no qual funciona, atualmente, a Secretaria da Educação. Esse Instituto foi fundado em 1846, e não se esqueçam que eu continuava pobre. Quando completei 18 anos, meus pais vieram para cá, com meu irmão; eu já trabalhava durante o dia e estudava à noite; era, portanto, bastante independente, embora não o fosse totalmente do ângulo financeiro. Precisava me profissionalizar rapidamente, enquanto trabalhava como secretária. Houve ocasião em que cheguei a ter três empregos, simultaneamente. Pela manhã ia a um emprego; à tarde, a outro; à noite, estudava e, entre as 17 horas, quando deixava o trabalho, e as 19 horas, quando entrava na Escola Normal da Praça, dava aulas particulares. Começava sempre ensinando português, sendo, até hoje, muito rigorosa com a escrita e a fala desta língua e de outras, mas acabava acompanhando os adolescentes ginasianos em praticamente todas as disciplinas.

Lembro-me do quão importante foi, para mim, uma família japonesa, cujas crianças/adolescentes foram meus aluninhos. Obviamente, falando só japonês, em família, as crianças iam mal na disciplina Português, na escola. Rigorosamente, não sabendo a língua oficial da escola, não aprendiam nenhuma matéria. Acabei dando aulas a eles de todas as disciplinas. Ofereciam-me um lanche, que eu tomava, sem parar de ministrar minhas aulas. Esse lanche tinha enorme importância para mim, pois eu não podia comprar nada semelhante. Até hoje, adoro uns biscoitos japoneses, feitos de arroz, em virtude de ter-me habituado a comê-los naquela casa. Nessa época, eu fazia o Curso Normal, o que me permitiria mais rápida profissionalização. Quando o concluí, quis fazer o Curso de Aperfeiçoamento para Professores Primários, que funcionava no período matutino. Passei, então, a estudar pela manhã e trabalhar à tarde e à noite, sempre aproveitando o intervalo entre um e outro emprego para dar aulas particulares. Como secretária de um senhor que exportava lã uruguaia, tinha seu casal de filhos, Maria Olívia e Eduardo, como alunos quase permanentes. Nas noites em que não dava aulas particulares, estudava ora inglês, ora francês. No Yázigi, fiz dois estágios, ou seja, o total existente naquela época. Meu professor de inglês, nessa instituição, que era palestino, montou sua própria escola. Como suas aspirações extrapolavam o ensino apenas de inglês, pensou em oferecer o ensino do idioma português para estrangeiros. Solicitou-me, então, a criação de um método de ensino do português para estrangeiros. Não sei como consegui fazer, era muito jovem, tinha meus 19, 20 anos. Elaborei o método, que foi testado e aprovado por esse professor, cujo nome não me ocorre.

Concluí o Curso de Aperfeiçoamento, em 1954, tendo sido a primeira colocada na classificação geral. Essa posição deu-me cadeira-prêmio. Isso significava que eu passava na frente daquele imenso número de normalistas, que eram professoras-substitutas, às vezes por muitos anos, e haviam 
reunido, em função disso, um certo número de pontos com os quais disputavam uma cadeira no Magistério Primário como efetivas. Havia, também, as que já gozavam desse status, mas não queriam mais permanecer numa pequena cidade do interior do Estado, preferindo lecionar na capital. Elas tinham muita prática e, também, alguns vícios. Eu, não obstante ser especializada e, desse ângulo, mais preparada que elas, nunca havia enfrentado uma classe no dia a dia. Como premiada por cadeira-prêmio, escolhi o Grupo Escolar "Paulo Setúbal", na capital. Escapei daquela peregrinação por fazendas, microvilas, cidadezinhas, cidades, até chegar à capital. Trabalhei muito pouco como professora primária. No ano de 1955, fiquei trabalhando como secretária, preparando as aulas que daria no "Paulo Setúbal" e esperando sair minha nomeação, evento que só ocorreu em outubro. O ano estava praticamente findo e eu o havia perdido em termos de estudo. Prestei vestibular na Faculdade de Filosofia, Ciências e Letras da Universidade de São Paulo, no início de 1956.

Naquela época, a legislação era uma para quem fizesse o colegial, dividido em científico, que encaminhava para as chamadas ciências duras, e o clássico, que dirigia os estudantes ao estudo de línguas e literaturas. O Curso Normal era regido por legislação especial. Só dava direito ao vestibular para os cursos de Pedagogia e de Ciências Sociais. Tive o bom senso de escolher este último. Eram muito poucos os vestibulandos que conseguiam entrar na Faculdade. Em minha turma, entramos 16. Eu, que não podia pagar cursinho e, para piorar as coisas, não havia feito o científico, consegui entrar e ser sempre uma das primeiras alunas. O professor Florestan Fernandes, meu grande mestre, desempenhou papel muito importante, posteriormente, em minha carreira. Sempre o tive como um grande intelectual e um ser humano de primeiríssima qualidade. Havia, contudo, naqueles tempos, uma enorme distância entre professores e estudantes. Até a última vez em que conversei com ele, o tratei de professor e senhor, como faço até hoje com o professor Antonio Candido, também este meu professor de Sociologia, antes de passar para Teoria da Literatura.

Em 1954, quando estudava pela manhã, fui à escola à noite, a fim de procurar um livro e uma sala de aula tranquila, para lê-lo e fumar um cigarro. Ao procurar a sala, encontrei o professor Waldemar Saffioti - ele era professor do Instituto de Educação "Caetano de Campos", já era doutor em Química e estava fazendo o curso de Física - sentado à mesa do professor, estudando. Fiquei atrapalhada, quando o vi lá, justamente porque ele era o professor e lhe pedi desculpas, fiz menção de sair, mas ele disse que eu ficasse, porque ele também estava estudando. Disse a ele que também queria fumar (estudantes eram proibidos de fumar no interior da escola). Ele me mostrou seu cigarro e me disse que poderia fumar à vontade. Começava, assim, nosso relacionamento; ele era o professor, embora eu não tenha sido sua aluna, e eu, a estudante.

Retomando minha entrada na USP, como perdi três anos, em Auriflama, e mais o ano de 1955, esperando minha 
nomeação, entrei na Faculdade com 22 anos. Comecei o curso de Ciências Sociais, em 1956, junto com Eva Blay, com Carmuti e tantos outros. Como me casei em 1956 e fiquei, com meu marido, um ano nos Estados Unidos, atrasei-me um ano, o que me deu a oportunidade de pertencer a uma turma da qual resultaram excelentes intelectuais, como Michel Lövy, Roberto Schwarz, Gabriel Bolaffi, para citar apenas alguns. Tão logo me formei, inscrevi-me, com Octávio lanni, para fazer curso de especialização, uma vez que a pós-graduação não estava ainda organizada, não existia. Naquela época, a legislação permitia ao portador do diploma de normalista fazer o curso de Pedagogia ou Ciências Sociais e, como sempre fui muito inconformada com as injustiças, caí no lugar certo. Entrei na Faculdade com quatro anos de atraso. E eu sabia que precisava me profissionalizar rapidamente, porque minha família precisava de minha contribuição. Finalmente, ganhava um salário bom, como professora da rede estadual; eu me havia tornado caloura - bicho, como se dizia na ocasião, ao ser aprovada no vestibular da Faculdade de Filosofia, Ciências e Letras da USP. Os bailes dos bichos eram à tarde, pois mocinhas daquela idade não frequentavam bailes à noite. Como eu era bicho, fui ao baile com Ruth, uma amiga e vizinha. Novamente em virtude do vício do tabaco, que, felizmente, abandonei, fui parar na mesa do professor Saffioti. Acabamos por dançar a tarde toda. Com Ruth ocorreu o mesmo. Saímos, os dois casais, e fomos a um cinema.

Começara, assim, meu curto namoro com Saffioti. Era $1^{\circ}$ de Maio e houve mais dois feriados naquele mês, no ano de 1956. Saímos mais duas vezes, então. Ele não me convidava para sair nos fins de semana, o que me parecia estranho. Muito mais tarde, fui saber que ele passava os fins de semana com sua mãe e uma irmã, em Campinas, onde elas residiam, porque seu pai havia ido à Itália. Ainda saímos, em junho, mais uma ou duas vezes, tendo ele partido para o Rio de Janeiro, já que havia ganhado uma bolsa do CNPq, para fazer pesquisa em Manguinhos. Foi marcado, entre nós, um encontro num sábado, depois de duas semanas. Mas, após uma só semana, Saffioti foi me encontrar na Faculdade, na qual eu fazia exame de Filosofia. Perguntou a que horas eu sairia e me anunciou que iria me apanhar por volta de 19 horas. Efetivamente, levou-me a um restaurante, no qual jantamos. Como havia saído sua bolsa para estudar energia nuclear nos Estados Unidos, pediume em casamento. No dia seguinte, ele teria que preencher um formulário para viajar, dizendo se ia solteiro ou casado, já que o valor da bolsa variava em função desse dado. Passei a noite toda pensando: caso ou não caso? Consultei um tio, que me disse: "seus pais já viveram a vida deles, viva a sua!". No dia seguinte, eu disse: "mamãe, vou me casar". Casei sem plano algum, sem enxoval algum, não tinha sequer um pano de prato, pois sempre dizia que não me casaria. Casei-me e, após quatro dias no Rio de Janeiro, viajamos para os Estados Unidos. Fui para lá já falando inglês. Fiz também um curso de criminalidade numa universidade norte-americana, numa pequena cidade da Pensilvânia. Voltamos, terminei a Faculdade em 1960. Até 
há pouco tempo, eu me correspondia com as amizades feitas em 1956, nos Estados Unidos. Comecei minha carreira acadêmica com 27 anos, apenas um ano depois de haver terminado a graduação em Ciências Sociais. Aos 33 anos, graças à visão política do professor Florestan Fernandes, já era livre-docente, em Sociologia, da Faculdade de Filosofia, Ciências e Letras de Araraquara [FFCLA], da hoje UNESP [Universidade Estadual Paulista "Júlio de Mesquita Filho"].

\section{JC: E os estudos sobre a mulher, quando começaram?}

HS: Isso começou em 1962. Em 1960, Saffioti trabalhava na Química da USP. Nós voltamos dos Estados Unidos para ele trabalhar no reator nuclear de pesquisa da USP. Como ele era físico e químico, era o ideal para essa área. Entretanto, como discordava visceralmente da maneira como o professor Marcelo Damy de Souza Santos coordenava as atividades do pessoal que trabalhava no reator, demitiu-se. Logo em seguida, foi convidado por um outro setor da Química da USP, tendo conjugado o trabalho em cristalografia com o de docente do Instituto de Educação "Caetano de Campos", escola de muito prestígio. Em 1960, ele recebeu o convite para fundar o curso de Química, na posteriormente chamada Universidade Estadual Paulista "Júlio de Mesquita Filho", então denominada Faculdade de Filosofia, Ciências e Letras de Araraquara. Cumpriu a missão a ele atribuída pelo professor Paulo Fonseca, docente da USP e primeiro diretor da FFCLA e, depois, organizou o Instituto de Química da mesma instituição. Em 1961, ele viajava entre São Paulo e Araraquara, vindo nos fins de semana se reunir a mim. No final do ano, fizemos um balanço e achamos muito ruim aquela vida. Então, resolvemos constituir uma nova residência em Araraquara. Eu precisava ir, porque ele já tinha um emprego naquela cidade e eu necessitava também ter o meu. Como eu tinha ficado quatro anos comissionada na USP e um ano afastada sem vencimentos, quando fomos para os Estados Unidos, não tinha mais direito de pedir afastamento, porque tal benefício era concedido apenas uma vez. Então, solicitei um comissionamento para desempenhar qualquer função na FFCLA, tendo este sido negado, a meu ver, com toda razão. A única maneira de obrigar a Secretaria da Educação a me comissionar, naquele momento, era prestar vestibular, desta vez na UNESP, e ser aprovada em primeiro lugar, porque, nesse caso, a lei a obrigaria a me comissionar. Fiz vestibular para Pedagogia e obtive a primeira colocação.

Quando estava fazendo o último exame, o professor Luiz

${ }^{1}$ Luiz Pereira é autor de várias contribuições pioneiras da área de Sociologia, dentre as quais cabe realçar o livro Trabalho e desenvolvimento no Brasil (PEREIRA, 1965). Pereira, docente de Sociologia na FFCLA, convidou-me para trabalhar com ele e, então, fui dar aulas para os colegas que haviam prestado comigo o vestibular. ${ }^{1}$ Luiz tinha grande capacidade e inteligência, pena que faleceu tão jovem, com menos de 51 anos. Já havia feito seu doutorado, quando me 
fez o convite para trabalhar com ele, tendo ficado apenas mais um ano em Araraquara, depois de minha contratação. Logo no início, ele me atribuiu a disciplina Introdução à Sociologia, do primeiro ano, e Metodologia, que era ofertada no terceiro ano. Eu queria morrer, porque, quando terminamos a faculdade tomamos consciência de nossa imensa ignorância. Trabalhei muito, fiz o que pude. Em 1964, Luiz veio para São Paulo. Primeiro, para o Centro de Estudos de Sociologia Industrial e do Trabalho [CESIT]; depois, como docente da USP. Então, fiquei na UNESP, completamente sozinha, sem ter a quem recorrer, caso encontrasse um problema sério para cuja solução não estivesse preparada. Eu ministrava aulas de todas as disciplinas, cheguei a dar aulas inclusive aos domingos! Saffioti chegou a ministrar oito disciplinas, porque não havia mão de obra qualificada. Nessa época, havia uma norma extremamente injusta, a meu ver, pois, independentemente do momento em que o professor houvesse começado sua carreira acadêmica, tinha que apresentar sua tese de doutorado ou de livre-docência, até dezembro de 1966, para o Conselho Estadual de Educação, ao qual éramos sujeitos. Eu achava muito injusta essa regra, mas pensava que, como mulher e marxista, deveria cumpri-la. Do contrário, não seria recontratada. Os preconceitos contra mulheres eram ainda muito mais numerosos e fortes, então, do que hoje. Ademais, esta mulher era (e é) marxista, e o Brasil, a partir do golpe militar de 01.04.1964, vivia sob um regime ditatorial, em certos períodos, terrivelmente sanguinário.

Devido a essa norma, não tive tempo de fazer especialização. Fiz minha inscrição no doutorado, na USP, com o professor Florestan Fernandes. Escrevi e apresentei o trabalho a meu orientador, que o criticou duramente, dizendo-me, ao mesmo tempo, que não patrocinaria meu doutoramento, uma vez que desejava que eu fosse, diretamente, para a livredocência. Fiquei quase louca, porque, se o trabalho merecia críticas tão sérias, não era de boa qualidade. Assim, como poderia eu enfrentar uma banca examinadora de cinco professores, altamente gabaritados? Durante umas duas semanas, eu pensava não ser capaz de realizar nada adequado para obter o título de livre-docente, como queria meu grande mestre. Depois de uns 15 dias em órbita, entrou, novamente, em minha vida, aquela atitude de tomar tudo como desafio. Decidi mostrar para ele que eu tinha fibra. Aceitei certas críticas, que me pareceram absolutamente pertinentes e reforcei aquilo que ele havia criticado e que não me parecia pertinente. Vejam que petulância! Será que ainda hoje a carrego? Naquela época, não havia xerox, havia muito pouca literatura específica e muitas aulas a dar. Não sei como dei conta de tudo! Atualmente, com o computador, tudo se resolve de forma mais rápida.

Na máquina de escrever manual, eu fazia as notas de rodapé e, não sei como, dava tudo certo. Nunca precisei sequer colar um pedaço de papel numa folha. A norma era a seguinte: primeiro o texto era datilografado, em seguida era entregue para um especialista em datilografia em estêncil e, por último, 
ia para o mimeógrafo. O sistema de confecção das brochuras era extremamente frágil. Como minha tese tinha 520 páginas, não era possível fazê-la em um só volume. Se eu fizesse em dois volumes, como o livro é dividido em três partes, iria ficar um livro grosso e outro fino, parecendo apêndice. Resolvi, então, fazer em três volumes, acompanhando a divisão interna da tese. Depois que a entreguei, prontinha, para o professor Florestan, e ele a leu, disse-me que eu deveria ter guardado o terceiro tomo para o concurso de cátedra, ainda existente, pois a reforma universitária só ocorreu em 1968. A propósito de minha tese, tivemos apenas um encontro, no qual ele criticou o trabalho. Eu não podia contrariá-lo, porque ele era "o papa" da Sociologia no Brasil, com muita justiça, pois já havia escrito muitos livros de grande valor. Eu tinha apenas duas opções: ou a livre-docência ou a não titulação, já que ele não patrocinaria meu doutorado. Fui para a livre-docência, entrando pagã, sem o padrinho existente no doutorado, ou seja, o orientador. Entreguei a tese em dezembro de 1966 e ela foi enviada para o Conselho Estadual de Educação [CEE]. Havia um conselheiro-padre, de cujo nome não me recordo. Ele adoeceu e teve a brilhante ideia de levar minha tese para leitura, durante sua convalescença, no hospital. Claro que ele deve ter piorado várias vezes. Quando melhorou, ele fez um discurso acalorado no CEE, dizendo que se tratava de uma candidata comunista (não se esqueçam de que o golpe militar tinha ocorrido em 1964), que só conhecia o Manifesto do Partido Comunista e que tinha a veleidade de criticar Weber. Então, armaram uma guerra psicológica, que durou aproximadamente três semanas, dizendo-se que substituiriam minha banca inteira, composta por Florestan Fernandes, Ruy de Andrada Coelho, Antonio Candido, Gioconda Mussolini e Luiz Pereira. Ruy Coelho, que, aos 18 anos, escrevera um ensaio sobre Proust, era inteligentíssimo e bem situado na vida, e Antonio Candido, que havia afirmado que os sociólogos escreviam muito mal, disseram estar muito bem impressionados comigo, porque eu escrevia muito bem. ${ }^{2}$ 


\section{Parte II - Gênero, violência e outros temas}

JC: Em qual momento você começou a trabalhar com violência?

HS: Quando Luiz Pereira veio para São Paulo e fiquei sozinha, em Araraquara, dando numerosas aulas, eu dormia, no máximo, quatro horas por noite. Hoje, não aguentaria mais esse ritmo. Fui incorporando pessoas que poderiam me ajudar. Como não sou nenhuma salvadora do mundo, fui conseguindo alguns assistentes, mesmo em meio às dificuldades, seja pela falta de verba, seja pela falta de qualificação. O fato é que, durante anos de trabalho, lutei muito para criar uma pós-graduação, lecionando conteúdos que não dominava senão com muito estudo pelas madrugadas, inclusive aos domingos. Como acredito que Universidade que se preze tem que oferecer uma pós-graduação que também se preze, eu sabia que, naquela altura, em 1978, poderia oferecer isso em Araraquara. Lutei durante cinco anos para criar a pós-graduação, que coordenei durante dois anos. Então, orientei Terezinha D'Aquino Ricci, cuja dissertação é digna de elogios, intitulada Trabalhadoras do barro: oleiras e olheiras, defendida em 1986. O mestrado começou a funcionar em 1981. Na segunda turma, uma aluna manifestou interesse por estudar violência contra mulheres, escolhendo-me como orientadora. Essa era uma temática que me intrigava muito. Acontece que, logo em seguida, recebi um convite do governo Francês, por intermédio e indicação de Maurice Godelier, que me telefonou, quando era diretor do Centre National de la Recherche Scientifique [CNRS], me convidando para ser pesquisadora associada, durante o ano de 1984, em Paris. Eu não poderia aceitar o convite por todo esse tempo, tendo-o aceito apenas por três meses. Permaneci ajudando o professor Ignacy Sachs, na Maison des Sciences de L'Homme [MSH]. Fiz o que me interessava: estudei, fiz seminários, pesquisei.

Começara a estudar violência contra mulheres, no ano anterior, para orientar a estudante, cujo interesse era esse. Assim, desde 1983, tenho me ocupado com essa temática. Fiz até uma pesquisa bem pesada sobre abuso incestuoso. Embora seja lamentável, o grande vilão, nessa história, é o pai biológico, cujo comparecimento foi de $71,5 \%$; seguido, muito de longe, pelo padrasto, com 1 1,1\%. O homem destrói seu próprio fruto.

JC: Na França, você trabalhou com a temática da violência?

HS: Eu li muito, fiquei amiga de Marie-Victoire Louis, que é a papisa da violência na França. Também desenvolvi relações de amizade com sociólogas como Helena Hirata, Danièle 
${ }^{3}$ SAFFIOII, 1969.
Kergoat, Hélène Le Doaré, que já havia conhecido bem antes pelo fato de termos uma amiga comum, e outras. Aliás, conheci Hélène Le Doaré muitos anos atrás, uma vez que ela era amiga de outra amiga francesa, Jacqueline Weisslitz, também socióloga, com a qual assisti a seminários em 1970. Participei do colóquio de Simone de Beauvoir, em janeiro de 1999, em Paris, e meu primeiro livro, A mulher na sociedade de classes: mito e realidade, ${ }^{3}$ só não foi publicado na França porque há nele críticas à prática psicanalítica. Não de toda a teoria psicanalítica, mas, sobretudo, da prática psicanalítica. Então, saiu em inglês, tendo sido muito resenhado na Europa, em vários países, em alguns dos quais se falam línguas que nem sequer leio. Esse livro foi minha livre-docência. Continuo endossando a tese central desse livro e, às vezes, ela é contestada, porque as/os leitoras/es não percebem que trabalho sempre com o conceito de Modo de Produção Capitalista [MPC], enquanto Cristina Bruschini, por exemplo, não cogita desse conceito. A tese central é a de que o modo de produção capitalista alija força de trabalho do mercado, especialmente feminina. Algumas feministas, munidas das tabelas tão bem construídas por Bruschini, argumentam contra minha tese. Nunca se perguntam em que atividades trabalham mulheres. Mais de metade das trabalhadoras, no Brasil, estão em atividades pelas quais o MPC não tem o menor interesse. Como é público e notório, o MPC procura, sempre, os setores mais rentáveis da economia. As atividades que mais empregam mulheres não se encaixam nesses setores. Embora não se possa afirmar que estes últimos não tenham nenhuma ligação com o capitalismo, podese, sim, asseverar que tais atividades, cuja absorção da força de trabalho feminina é expressiva, não foram organizadas em moldes capitalistas, ou seja, segundo os requisitos do MPC. Por outro lado, escreveria de outra maneira aquele livro. Naquela época, era obrigatório usar uma linguagem hermética, que só era compreendida por iniciados. Hoje, eu o redigiria em linguagem simples, a fim de tornar o livro accessível a um segmento muito maior da população. Que ele fosse compreendido, pelo menos, por todas as mulheres.

JC: Poderia citar alguns trabalhos sobre violência hoje no Brasil?

HS: O pessoal da Universidade Federal de São Paulo [UNIFESP], Eleonora Menicucci, por exemplo, participou de bancas de doutorandas minhas, a meu convite. Revela experiência na área e muita perspicácia. Na Pontifícia Universidade Católica de São Paulo [PUC-SP], eu não oriento apenas sobre gênero. Tenho um orientando, Carlos Roberto Araújo, economista, no qual deposito uma enorme esperança e cuja tese intitula-se Política e economia na globalização hegemônica. Já discuti com ele sobre a obra de Rosa Luxemburgo, à qual devoto 
${ }^{4}$ CASTELLS, 1999, 2000 e 2001.

${ }^{5}$ CASTELLS, 2000, p. 278.

${ }^{6}$ JOHNSON, 1997. profunda admiração, porque ela teve o topete de discutir o esquema da reprodução ampliada, de Marx, e mostrar que, de seu ângulo de visão, ele estava errado. Isso levou intelectuais a perceber diferenças entre conceitos, por exemplo, entre MPC e Formação Social Capitalista [FSC]. Não que ele estivesse errado, porque sabemos que ele trabalhava em um nível de abstração bem alto, ou seja, o do modo de produção capitalista, enquanto Rosa analisava a acumulação do capital num nível muito mais concreto, isto é, o da formação social, no qual estão presentes três contradições: a contradição entre capital e trabalho; nas relações de gênero, entre homens e mulheres; entre diferentes raças/etnias. Estas são as três contradições básicas, e, se não as levarmos em consideração, podemos produzir obras, cujo conteúdo seria, pelo menos, insuficiente para explicar a realidade brasileira.

Como isolar o conceito de gênero? Não se deve isolá-lo de seu contexto econômico, social e político. Aliás, eu utilizo cada vez menos esse conceito, porque gênero é um conceito a-político, a-histórico e bastante palatável. Tão palatável, que o Banco Mundial só financia projetos com recorte de gênero. Se fizermos referência à "ordem patriarcal de gênero", os projetos, certamente, não serão contemplados com as verbas solicitadas. Mas o patriarcado está aí, presente em todas as relações humanas. Chegamos ao paradoxo de os homens sustentarem a existência do patriarcado e a maioria das feministas mulheres a negarem. O espanhol Manuel Castells, meu amigo, publicou, há poucos anos, três livros ${ }^{4}$ sobre as sociedades em rede. No segundo, sobre identidade, Castells dedicou cento e tantas páginas ao exame da questão de gênero, apresentando dados de muitos países e, terminando esse capítulo, dizendo: "[...] o patriarcalismo dá sinais no mundo inteiro de que ainda está vivo e passando bem, apesar dos sintomas de crise...". ${ }^{5}$ Allan Johnson e vários outros homens feministas afirmam que o patriarcado existe e está aí. ${ }^{6}$ As mulheres dizem que não, que é coisa de rinoceronte ou de dinossauro. Não se trata de todas, obviamente, mas creio que de sua maioria. Eu tenho muito orgulho de ser um desses dinossauros.

Simone Becker: Quais são as pesquisas que você está desenvolvendo atualmente?

HS: Tenho trabalhado com violência, mas sem desprezar os outros temas. A Fundação Perseu Abramo realizou uma pesquisa sobre a mulher brasileira e o mercado de trabalho. Estava organizando uma coletânea com vários textos sobre esse tema e me pediu um artigo. Eu o escrevi, remetendo-o por e-mail à EFPA [Editora Fundação Perseu Abramo]. Dias pois, recebi um telefonema de uma representante da EFPA, dizendo-me que eu Ihe havia enviado um livro e não um artigo, porque enviei 62 páginas em uma fonte pequena e em espaço simples. Então, ela me encaminhou para Flamarion Maués, chefe da editora, 
cuja sugestão a mim apresentada foi a de retomar a última parte do artigo e, reduzindo-a sobremaneira, transformá-la em um texto com 15 páginas, no máximo. Ele disse: "aquilo que a senhora considera um artigo é um livro e a editora tem interesse em publicá-lo". Esse é um livro sobre violência, sem tratar exclusivamente de violência. Fala sobre história, sobre provas arqueológicas e paleontológicas, sobre a maneira como eu concebo "gênero" e sobre a "ordem patriarcal de gênero", dentre outros temas.

JC e SB: Você poderia falar sobre a sua relação com a militância, com o movimento feminista? O que você acha da relação entre academia e militância?

HS: Considero que há militantes que são exclusivamente militantes. Em geral, são pessoas que não leem, não discutem. Mas me identifico muito com alguns movimentos, me dou muito bem com as militantes do GELEDÉS e do Fala Preta, recebendo, muitas vezes, pedidos delas para eu escrever mais sobre racismo, porque dizem que sou a feminista que mais abordou esse problema, desde o início, porque, no primeiro livro, eu já abordava essa questão. ${ }^{7}$ De modo geral, tenho sido convidada para dialogar com os movimentos, embora não seja filiada a nenhum deles, porque isso me obrigaria a tomar posição. É óbvio que não existe ninguém que consiga ficar neutro diante de uma contenda. Tenho minha posição, pública e notória, mas não tenho filiação, porque não quero perder minha liberdade de pensamento. Quando me convidam, seja qual for o movimento, mesmo que se trate de partidos políticos com os quais não me identifico, procuro participar. Em geral, me pedem para falar sobre a minha teoria das relações de gênero e sobre a história do feminismo, no Brasil ou no mundo. Já fiz, também, muitas palestras sobre violência e sobre várias outras temáticas direta ou indiretamente vinculadas ao gênero. Outros assuntos caem no âmbito de meus interesses, como as diferentes maneiras de abordar gênero, no fundo, métodos de interpretação; a quem serve a globalização; cursos monográficos, como, por exemplo, sobre Weber, sempre focalizado do ângulo metodológico, o mesmo podendo ser realizado com outros sociólogos clássicos.

SB: Quais são os temas que você acha importantes no momento?

HS: Sempre me dei conta da importância das diferentes religiões, mas, ultimamente, considero imprescindível conhecêlas, pois elas penetram em todos os poros do indivíduo e do tecido social. As pessoas são cristãs, protestantes ou católicas, católicas ortodoxas ou católicas brasileiras, se curvam ou não se curvam aos princípios religiosos etc. Estamos entupidos de 
cristianismo e isso representa uma face do fundamentalismo. Odeio fundamentalismos. Caso tivesse tempo, estudaria a obra de Weber sobre religião, dessa perspectiva. Quando ministro cursos sobre Weber, não me preocupo em ensinar os tipos de dominação, porque isso qualquer pessoa medianamente inteligente é capaz de ler e de dar conta sozinha de aprendêlo. Prefiro explorar Weber do ângulo metodológico, entro no universo que ele construiu, que é totalmente falso, porque, para ele, não há ontologia. Não há sequer uma totalidade social; mas tão somente caos. Não gosto do pensamento pós-moderno, porque é fragmentário e projeta essa fragmentação na realidade, quando, para mim, a sociedade é uma totalidade, e a crença nisso me fez progredir teoricamente. No Brasil, sou considerada a teórica feminista, o que não significa que não sei pensar em políticas públicas, nem tampouco que não existam outras estudiosas do tema, criando teorias. Estudo o tema violência com a finalidade de lançar políticas públicas para as mulheres, oferecendo-as aos governantes, cujos meios para sua implementação estão ao seu alcance. A homenagem que muitas mulheres receberam, dentre elas eu, em julho de 2004, em Brasília, foi exatamente na Conferência de Políticas Públicas para as Mulheres. Logo, não sou apenas teórica, gosto também de pensar nas práticas, embora não me vincule a nenhum movimento, mantendo muito boas relações com todos eles. Não me agrada nada, nada, esta divisão: feminismo acadêmico versus feminismo militante. No Brasil, a academia abriu, sem resistência digna de nota, suas portas à temática de gênero e, ademais, há um trânsito fácil entre acadêmicas e militantes, sem contar o fato de que muitas militantes são também acadêmicas ou, pelo menos, leem e discutem suas leituras, não sendo, por conseguinte, apenas militantes.

\section{SB: Você tem ofertado cursos e publicado em parceria?}

HS: Sim, por exemplo, Suely Souza de Almeida e eu oferecemos um curso, no Rio, para a polícia militar. Lamentavelmente, foram escolhidos comandantes e subcomandantes, quando nós preferíamos aqueles policiais que ficam nas ruas, a fim de prevenir violências. Dei a maior parte das sessões, mas Suely colaborou. Ela é da Universidade Federal do Rio de Janeiro [UFRJ] e colaborou comigo, também, no livro Violência de gênero: poder e impotência, tendo escrito alguns capítulos. ${ }^{8}$

SB: Qual foi a temática do curso e como essa temática aparece na sua produção recente?

HS: A temática do curso foi a violência contra mulheres, sobretudo a violência doméstica. Há uma taxionomia por mim construída, publicada num artigo meu, ${ }^{9}$ e que retomei no livro 
${ }^{10}$ SAFFIOTI, 1969. já citado, publicado pela Editora Fundação Perseu Abramo. ${ }^{10}$ Boaventura de Souza Santos afirma que o espaço doméstico é o repouso do guerreiro, o espaço da privacidade, do feminino. O espaço doméstico é indiferenciado, para esse autor. Escrevi um primeiro artigo contra essa taxionomia, porque entendo que esse espaço não tem nada de indiferenciado. Ele é ultradiferenciado. Se eu recebo uma visita com a qual não tenho intimidade, a visita fica na sala; se é uma pessoa mais íntima, levoa para a cozinha. Se eu quiser ter privacidade para conversar determinado assunto com ela, me tranco no meu quarto, com minha visita. Nesse artigo, afirmo que prefiro pensar numa outra taxionomia. É claro que o espaço doméstico é eminentemente feminino, mas não é o espaço da privacidade. É o espaço do trabalho não reconhecido, do trabalho não pago, do trabalho doméstico.

E por que razão não é o espaço da privacidade? Porque vige um regime social, político e econômico androcêntrico ou patriarcal ou viriarcal. Em outros termos, vivemos sob o patriarcado. No Código Civil, que vigorou de 01.01.1917 a 10.01.2003, havia o débito conjugal, que, embora no Código fosse um direito/obrigação recíproco, na prática, só funcionava em mão única, isto é, contra a mulher. Se o marido desejasse ter uma relação sexual, e sua mulher não estivesse a fim disso, naquela noite, a relação aconteceria contra a vontade da esposa. Essa conduta se caracteriza como crime de estupro, artigo 213 do Código Penal. Se tomarmos o artigo 213 do Código Penal, vamos observar que o estupro se enquadra nisso, pois se há na casa um lugar da intimidade, esse pode ser também o lugar do crime de estupro. Diante disso, eu pergunto: onde é que está a intimidade, a privacidade, para mulheres? Onde está a privacidade da mulher, se ela é confinada ao espaço doméstico, ou ainda que não seja confinada, que participe também do público, que espaço doméstico de privacidade é este, no qual a mulher não tem privacidade? Tem alguma? Não tem, a maioria não tem. Nós, de classe média, classe média alta, temos. Por quê? Porque nós nos casamos com pessoas do nosso nível. Lembro-me de que, em nossa casa em Araraquara, havia um casal de empregados. O homem cuidava da chácara, era caseiro, e a mulher era empregada doméstica. Quando ela se referia a relações sexuais com seu marido, sua linguagem relativa a seu marido era a seguinte: "quando ele quer me usar...". Era essa a linguagem utilizada, nunca me esqueci; e já ouvi essa expressão sendo utilizada por muitas mulheres do Nordeste, que moram aqui, em São Paulo, de paulistas e de mulheres de outros recantos do país. Ou seja, elas se consideram objetos para o uso e o abuso do seu amo e senhor.

SB: A própria legislação deixa claro, de algum modo, que o casamento pode gerar estupros. Basta relatar a maneira como ocorreu a relação sexual, contra a vontade da mulher, à autoridade policial e esta enquadrará, imediatamente, o ato criminoso no artigo 213 do CP. 
1 PATEMAN, 1993.

${ }^{12}$ SAFFIOTI, 1992.

HS: O Código Penal está cheio da expressão "mulher honesta". O casamento é um contrato, que dá ao homem o título de patriarca e o direito de exercer seu domínio. Há um livro estupendo, intitulado O contrato sexual, de Carole Pateman, ${ }^{11}$ uma cientista política feminista, que examina o contrato de casamento à luz das teorias do contrato, mostrando que esse tipo de contrato permite o estupro. O livro merece os mais exultantes encômios pela maneira como foi redigido e pelas evidências nele reveladas. Além disso, deve ser divulgada sua existência e excelente qualidade em virtude de a Ciência Política ser a área das Ciências Sociais mais refratária aos estudos de gênero.

SB: Você fez curso de Direito, mas sempre atuou como socióloga, não?

HS: Tinha uma ilusão de que, me aposentando como socióloga, pudesse abrir um escritório de advocacia para defender mulheres. O meio jurídico em geral é muito conservador, rançoso, machista. Só que me dei conta disso à medida que fui estudando violência, que não consigo descasar da Sociologia. É claro que uma das funções do Direito é descobrir as brechas para escapar dessas coisas, mas um/a sociólogo/a certamente faria isso melhor do que um/a jurista. O advogado pode ter uma visão ampliada do direito comparado, mas a visão da sociedade que o advogado tem é triste. Durante os anos de faculdade, me desentendia frequentemente não com os promotores, mas com os juízes. As brigas eram, fundamentalmente, com dois juízes, um que ministrava Direito Constitucional e outro, Direito Civil. Entretanto, fiz bons amigos entre os professores, mas briguei muito.

Quando terminei o curso, fiz exame para Ordem dos Advogados do Brasil, mas não tenho a carteira, porque perderam toda a documentação, em Araraquara. Não havia ainda me aposentado, legalmente da UNESP, e a OAB daqui não encontrava nenhum papel. Em São Paulo, é muito importante ter essa carteira, porque, se um advogado ou advogada sofrerem um assalto, podem sacá-la e dar voz de prisão para o assaltante. Em várias situações, tal carteira funciona, amedrontando a parte agressiva.

SB e JC: Quem você acha que está produzindo teoricamente na área de gênero?

HS: Tem muita gente produzindo, mas, criando teoria, não conheço ninguém. Escrevi o artigo intitulado Rearticulando gênero e classe social, publicado numa antologia organizada por Cristina Bruschini e Albertina de Oliveira Costa. Nele, faço um levantamento de tudo o que havia de ponta no feminismo, na época; fiz uma espécie de revisão bibliográfica, ${ }^{12}$ de estado da arte da questão de gênero. Hoje, esse artigo pede atualiza- 
${ }^{13}$ BUTLER, 2003.

${ }^{14}$ LAURETIS, 1987. ção. Atualmente, Judith Butler tem-se sobressaído. Ela fala em matrizes de inteligibilidade cultural do gênero. ${ }^{13}$ Gosto dessa ideia, mas não da conclusão a que ela chega. Na verdade, ela está trabalhando não em termos de gênero, mas com matrizes de gênero, contratos sexuais. Porque, se as estudiosas estiverem numa matriz subversiva, competitiva, de gênero, podem dar vários nomes para essas outras matrizes, que buscam hegemonia, sem, contudo, repetir Butler, cujo pensamento admite, explicitamente, que mulheres podem estar dentro e fora do gênero (pensamento bastante defendido por Teresa de Lauretis em seu livro Technologies of Gender ${ }^{14}$ ), este último lugar representando, para ela, a desordem de gênero, fazendo-a cair na polaridade durkheimiana: o normal e o patológico. E as matrizes secundárias, onde estão? Não me agradam as categorias binárias, minha cabeça não funciona dessa maneira. Funciona com uma lógica contraditória, cuja existência descobri em 1985, quando também pensei no nó ou novelo ou, ainda, na simbiose, historicamente formada pelas contradições (pilares, antagonismos, eixos) fundantes da sociedade ocidental moderna. Esse tripé, na verdade, existe em qualquer sociedade atual, mas a prudência recomenda, pelo menos, uma limitação às sociedades ocidentais de hoje.

JC e SB: Como tem sido sua experiência com outras Universidades?

HS: Até recentemente, eu fazia parte do corpo de orientadores da UNESP, me convidavam para dar cursos de duas ou três semanas. Certa vez ofereci um sobre Weber, mas cursos regulares deixei de ofertar. Afastei-me, porque não era justo que eu constasse como orientadora, porque isso poderia interferir na relação professor/aluno e ser prejudicial ao programa. Sou constantemente convidada para fazer palestras lá. O prefeito de Araraquara criou um Centro de Referência da Mulher, ao qual atribuiu meu nome. Na Universidade Federal do Rio de Janeiro, ministrei um curso para policiais militares, com Suely Souza de Almeida, sobre o qual já falei. Eles receberam muito bem o curso e tiveram uma boa participação. Deixei de trabalhar na UFRJ, porque o trabalho na PUC-SP aumentou muito. Ademais, esgotara a verba por mim conseguida, estando eu, naquela época, trabalhando graciosamente. Em São Paulo, a Dr. ${ }^{a}$ Maria Inês Valente, supervisora de todas as delegacias especiais de atendimento à mulher, me pediu para dar o curso para os policiais de São Paulo. Mas eu estava muito ocupada, ela cansou-se de me esperar e pediu para Silvia Pimentel montar o curso.

Sílvia marcou uma reunião, convidando a mim, Valéria Panjdardian e Flávia Piovesan, duas de suas ex-alunas, assim como a então presidente do Conselho Estadual da Condição 
Feminina, Sr. ${ }^{a}$ Maria Aparecida de Laia. Esta se encarregou de conseguir, junto ao governo de seu partido (PSDB), verba para xerografar os textos que distribuímos às delegadas, para cobrir as despesas de viagem, hospedagem e alimentação dessas profissionais, assim como um pró-labore para as professoras. As delegadas foram divididas em duas turmas, uma vez que eram numerosas, pois havia 121 delegacias de mulher no Estado de São Paulo. O programa que eu havia elaborado e ministrado no Rio de Janeiro foi a base, tendo sido incluídos alguns temas mais, como direitos humanos, a mulher e os meios de comunicação e um dia da programação para que a então presidente do Pró-Mulher, Malvina Muszkat, psicóloga, a fim de que ela mostrasse a perspectiva psicológica nos estudos sobre violência contra mulheres.

Minha prática com esses cursos vai um pouco além. Uma desembargadora paulista, Dr. ${ }^{a}$ Shelma Lombardi de Kato, que fez carreira em Cuiabá, Mato Grosso, conseguiu uma verba do Banco Mundial, destinada a reciclar profissionais da Magistratura e do Ministério Público, ensinando-lhes gênero, marcadamente violência de gênero. A Dr. ${ }^{a}$ Shelma formou uma equipe, da qual fiz parte. ĺamos a muitas cidades, em geral capitais de estados, a fim de dar aulas a operadores do Direito. Havia, além de Sílvia Pimentel e eu, dois homens fantasticamente bem qualificados, um juiz de Campinas, o Dr. José Henrique Torres, e um ginecologista obstetra, o Dr. Jefferson Drezett. Este último foi integrado na equipe já no final de nossos trabalhos, não porque já houvéssemos cumprido nossa missão, mas porque a verba terminara. Nesses cursos ou séries de seminários, algumas promotoras e/ou procuradoras haviam alcançado um bom nível de compreensão das questões de gênero, podendo auxiliar a Dr. ${ }^{a}$ Shelma. Foi o Dr. José Henrique Torres que deu as primeiras sentenças favoráveis a pedidos de autorização para a realização de aborto em casos de fetos portadores de anomalias graves e irreversíveis. Hoje, já existe uma jurisprudência de cerca de mil e quinhentos casos. É, sem dúvida, importantíssima esta terceira permissiva penal para o aborto. Há muitas pessoas lutando para a aprovação da súmula vinculante, não apenas para poupar trabalho. O juiz de primeira instância é aquele que vai para o interior e não vê mais nada, não tem universidade na cidade onde atua, ele não dá aula, não estuda. Se há um conflito entre um artigo de qualquer código comercial, tributário, penal, civil, ou qualquer outra lei isolada, de uma parte, e, de outra parte, a constituição, é obvio que prevalece a constituição, pois é a lei magna do país. Mas os juízes não estudam mais, então não percebem que estamos em outro mundo, que a constituição acabou por derrubar vários artigos do Código Civil e eles não podem atuar segundo aqueles artigos.

JC: O que a senhora acha dos estudos sobre masculinidades?

HS: Oriento, no momento, uma doutoranda - Francineide Pires Pereira - que está fazendo uma tese lindíssima, estudando 
masculinidades, mas dentro dessa lógica contraditória, porque ela adotou minha lógica, meu esquema teórico, e porque considero que, se existem diferentes naturezas de gênero para as mulheres, elas existem para os homens também, é óbvio. Sempre dou exemplos para os meus alunos, dizendo: vocês estão na sala de visitas da sua casa e, ao mesmo tempo, estão lá seus pais, sogros, filhos, netos, os amigos dos filhos e vocês não se dirigem da mesma maneira a cada um desses segmentos, vocês ocupam uma determinada matriz de gênero para se dirigir aos netos, aos filhos, aos amigos. Penso que o tempo não existe, é uma convenção, nós usamos um calendário, existem outros calendários. Teresa de Lauretis fala em estágios, dentro e fora do tempo. Não concordo com isso, ela não soube lidar com tempo/espaço, ou espaço/tempo, porque nós estamos simultaneamente dentro e fora. Porque, se nós somos capazes de nos dirigirmos de maneiras inteiramente diversas às pessoas e de maneiras que se chocam frontalmente, num mesmo espaço, e no mesmo tempo, é porque nós podemos estar simultaneamente dentro e fora do gênero. Nós não temos como estar apenas fora do gênero, nem nós mulheres, nem os homens. Como ficar fora do gênero? Isso é impossível. O que nós podemos é lidar com todas as matrizes que nós conhecemos, simultaneamente.

Então, a minha maneira de criar, porque eu não sou nenhum gênio, é: eu leio um livro, absorvo aquilo que me parece interessante, e tento avançar. Tento avançar um pouco - a ciência avança milimetricamente. Uma grande descoberta é fruto do acaso, porque ninguém é tão inteligente para ter uma ideia brilhante por semana. Então, vou fazendo o que eu posso, que é caminhar assim na criação, milimetricamente.

JC: Continuando com o tema da masculinidade, está se falando muito agora no homem, e ao mesmo tempo, na bissexualidade. O que você acha disso?

HS: Sempre, desde o início, nunca deixei de falar no homem, porque, se a sociedade castra mulheres, ela castra homens também, lógico! O saldo negativo é maior para a mulher, não tem dúvida nenhuma, mas o homem fica impedido de desenvolver sua sensibilidade, sua anima, e as mulheres são castradas em seu animus. Mas há mulheres que foram obrigadas a desenvolver seu animus, como eu, por exemplo. Só que desenvolvi também minha anima. Mas não sou mandona, não sou prepotente, sei ser delicada, mas não considero isso atributo natural de mulheres. Eduardo Mascarenhas tem um pequeno livro que se chama No divã do psicanalista. Num certo momento, ele afirma que a Igreja Católica faz um tremendo terrorismo para enquadrar todo mundo, homens, mulheres no heterossexualismo. A sociedade, 
a família, todas as instituições fazem terrorismo, porque todo mundo tem que ser heterossexual. Mas, se as pessoas não nascessem bissexuais, não haveria necessidade de tanto terrorismo. Então, embora eu tenha muitas críticas com relação à teoria freudiana, acredito piamente que todo mundo é bissexual, pelo menos ao nascer, e que a sociedade consegue formatar alguns como se formata disquete, e não consegue formatar outros, que são mais rebeldes, mais subversivos em relação às matrizes ou contratos sociais. É aquela história: não jogar o bebê fora com a água do banho, mas aproveitar o que se pode, e jogar fora o que considera descartável.

Não li a obra inteira de Jung, até porque é uma imensa quantidade de livros, mas sei que ele trabalhou com as noções de anima e animus. Ele chamava de princípio, que é uma palavra que não é de meu agrado. Cada cidadão ou indivíduo teria o princípio de anima e o princípio de animus. O princípio de animus é aquele que nos ativa, para arrombar portas e janelas, enfim, os obstáculos que se interpõem entre nós e os nossos objetivos. E anima seria o princípio da sensibilidade, da delicadeza. O que faz a sociedade? Considera que a mulher só pode desenvolver sua anima, quando todos os indivíduos possuem os dois; anima é o feminino e animus, o masculino. $O$ ideal seria que homens e mulheres desenvolvessem equilibradamente ambos. Tanto um quanto o outro. Acho que o encontro amoroso acontece quando isso se dá. Do jeito como as sociedades se comportam, o desencontro amoroso já está marcado, é destino, porque há um desequilíbrio total, uma parte é anima, e a outra parte é animus. Então uma não pode usar a razão e o outro não pode sentir, imagina! Acho que não dá certo nem no momento do orgasmo, não sei, estou metendo minha colher de pau aqui em área alheia. Mas gosto muito de trabalhar com anima e animus. Considero que estes são conceitos heurísticos e, portanto, positivos. Nada é fácil: conseguir o equilíbrio entre animus e anima tampouco o é.

SB: Você poderia citar algum ou alguns momentos que representam marcos na sua trajetória?

HS: Houve um momento de minha vida que foi de inflexão, um momento em que se descortinou uma nova dimensão da vida para mim. Isso ocorreu em 1985, quando escrevi, pela primeira vez, sobre a lógica contraditória. Telefonei para um grande amigo muito inteligente e lhe disse: "acho que estou ficando louca, porque acabo de escrever que a lógica formal não resolve os problemas, e que nós só vamos conseguir avançar descobrindo, refletindo e usando a lógica contraditória. Eu acho que eu estou louca, você não acha?". Ele respondeu: "de jeito nenhum, que maravilha que você descobriu, acho que é por aí mesmo". Ele me deu a maior força. Acho que nesse momento, sim, há um marco, ele é um marco em minha vida acadêmica. De produção científica, não de docência. 


\footnotetext{
${ }^{15}$ A entrevistada se refere à peça teatral Perdida, uma comédia romântica, encenada no Brasil em 2001 pelo Grupo Arte Ciência no Palco. Texto de José Sanches Sinisterra, dirigida por Marco Antônio Braz, com Oswaldo Mendes, Flávia Pucci e Carlos Palma.

${ }^{16}$ A peça Copenhagen estreou em 2000, montada pelo Grupo Arte Ciência no Palco. Texto de Michael Frayn, dirigida por Marco Antonio Rodrigues, com Carlos Palma, Oswaldo Mendes e Selma Luchesi.
}

Há obras teatrais que também são referências. Recentemente vi uma peça, chama-se Perdida, interpretada, dentre outros, por um primo meu, Carlos Palma. Pelo título, logo se pensa numa prostituta, mas não tem nada a ver com isso, tem a ver com o modo como as pessoas lidam com o espaço/tempo. ${ }^{15}$ A outra é Copenhagen, a meu ver, simplesmente deslumbrante. É uma conversação, uma interlocução entre, de um lado, Niels Bohr, que era um físico dinamarquês quando a Dinamarca estava ocupada pelos nazistas, e, de outro lado, Werner Heisenberg, também físico, mas alemão, produzindo sob as barbas da Gestapo. ${ }^{16}$ Uma coisa é trabalhar num país política e militarmente ocupado, outra coisa é trabalhar ali, juntinho da Gestapo, acho que é muito pior. E o Heisenberg fica um tempo na Dinamarca, trabalhando com Bohr, porque ele era o físico mais famoso, e se tratava da corrida pela confecção da bomba atômica. A mulher do Bohr participa da interlocução, e se fala de física o tempo todo, mas a peça não é, propriamente, sobre essa ciência, não obstante os dois serem físicos. A peça trata da responsabilidade do cientista, pois, enquanto Bohr agilizava todos os processos para que se chegasse à construção da bomba atômica o mais depressa possível, Heisenberg usava técnicas dilatórias para atrasar tal processo, porque, quanto mais ele conseguisse adiar o momento da finalização da bomba, menos pessoas morreriam. Imaginem bombas atômicas nas mãos de Hitler ou nas mãos do exército nazista! A peça trata, por conseguinte, da ética científica. Nós, cientistas sociais, temos muitas responsabilidades, porque criamos, sugerimos, participamos de políticas públicas, então nossa responsabilidade é enorme. Gosto muito de Teresa de Lauretis, gosto muito de um conceito dela que é o de sujeito múltiplo, que me permite lidar com a noção de espaço/tempo de uma maneira gostosa, agradável, simples. Já que eu não tenho o que eu tanto desejava, o dom da ubiquidade, que significa estar em vários lugares ao mesmo tempo (dez, para mim, seriam suficientes), simultaneamente, o que é impossível, caminhei como se faz em Perdida, pelo espaço/tempo. Vamos tomar dois teóricos ou duas teóricas, que podem ser contemporâneos/as e não coevos/as. Ou melhor, quando fiz o curso de Direito, era contemporânea daqueles juízes rançosos e machistas, o meu pensamento estava muito à frente do pensamento deles. E deve haver milhares de pessoas que estão muito à frente do meu pensamento, então somos contemporâneos e não coevos.

JC e SB: Você poderia citar algumas referências atuais do campo de gênero que você considera importantes?

HS: Na Espanha conheço poucas pessoas. Existe um doutorado sobre gênero na Universidade Complutense, em Madri. Eu conheço a estrutura do doutorado, sei quem são as docentes, os docentes, porque li textos de autoria de alguns deles. Há uma cientista espanhola de quem gosto, Célia Amorós, que elaborou

${ }^{17}$ AMORÓS, 1991 mais longe, como eu desejaria. Nem toca em ontologia. Não 
${ }^{18}$ JOHNSON, 1997.

tenho ido, recentemente, aos Estados Unidos, mas entrando, todos os meses, na Amazon, vejo o que há de novo, pois já conheço as grandes autoras e os grandes autores. O livro, já citado, de Allan G. Johnson, vocês não podem perder, não encontrei em nenhuma outra língua, só em inglês. ${ }^{18}$ Alguns estudantes leem capítulos, peço para resumirem para que os outros tenham uma ideia, dou aulas sobre as ideias de Johnson, mas eles não leem todo o livro. Há outras autoras francesas das quais gosto. Gosto de MarieVictoire Louis, que é a papisa da violência, na França; gosto de Colette Guillaumin, e também de Helena Hirata, mas ela é quase brasileira, embora tenha nascido no Japão, e conhece as três línguas: português, japonês e francês, pois vive e trabalha em Paris, há muitos anos, podendo fazer boas comparações entre os três países. O grupo do antigo GEDISST, que atualmente publica Cahiers du Genre, antes Cahiers du GEDISST, com quem trabalha Helena, é todo de alto gabarito.

Para citar apenas algumas, das quais me lembro agora, menciono Danièle Kergoat, Hélène Le Doaré, Eleni Varikas, Françoise Collin, Geneviève Fraisse e tantas outras e outros, pois também há homens. Michelle Perrot e Georges Duby organizaram a coleção História das Mulheres, obra de consulta indispensável. Mais do que isso, eles fizeram uma seleção bastante rigorosa dos artigos contidos nessa obra em cinco volumes. Em alguns círculos de nosso meio acadêmico, prevalece a divulgação de obras em francês. Por exemplo, quando houve o congresso sobre saúde e mulher no Hotel Glória (Women, Work, Health, 1999) tomaram a iniciativa de pedir para que todas as feministas enviassem previamente os seus programas de aulas (somente as que lecionassem em cursos de pós-graduação). Observei que apenas Miriam Adelman e eu tínhamos bibliografias majoritariamente em inglês, todas as outras as tinham em francês. As francesas fazem excelentes pesquisas sobre 0 trabalho da mulher e sobre história, mas não sobre metodologia. Eu continuo interessada em epistemologia e fascinada por ontologia. Esta última não existe tampouco nos Estados Unidos. É muito raro, lá, encontrar intelectuais interessados nisso, o que se pode explicar pela ausência de tradição marxista.

Com os interesses que alimento, talvez devesse estudar alemão. Mas já comecei duas vezes e desisti. A primeira razão era mesmo falta de tempo. Mas não posso descartar a interferência do inglês, quando abria a boca para pronunciar um daqueles palavrões (no tamanho) alemães. Como a Alemanha é o berço da filosofia, não tenho dúvidas de que deveria estudar alemão e ler autores não traduzidos para idiomas que conheço. Esse "projeto", todavia, ficará para uma outra existência, se isso for possível. Como não tenho essa crença, deixo a outras/os essa tarefa. Que a cumpram muito bem.

Estou certa de que a escolha da bibliografia não deriva apenas de o intelectual ter um domínio maior de um idioma que de outro. Obviamente, isso interfere no percentual de títulos de um certo idioma na totalidade das referências. O decisivo, contudo, é o assunto. Quando eu estudava trabalho feminino, 
usava muita bibliografia francesa, mas não deixava de utilizar, também, a de língua inglesa. Usei muitos dados estatísticos dos Estados Unidos, uma vez que eram bem coletados e bem apresentados, desagregados por sexo, portanto, muito superiores aos nossos. Isso não significa, porém, que não escondessem, na época, ou não ocultem, na atualidade, preconceitos de gênero. Está por nascer a sociedade que não os possua. Nossa luta, jovens, deverá construir logo esse tipo de sociedade. Mãos à obra, então. Não acham que já falei demais? Falando ou escrevendo, sou sempre prolixa! Perdão, meninas. Mas foram vocês que perguntaram. E se eu houvesse ficado calada? Talvez a decepção fosse maior, não é?

São Paulo, julho de 2004.

\section{Referências bibliográficas}

AMORÓS, Célia. Hacia una crítica de la razón patriarcal. 2. ed. Barcelona: Anthropos Editorial del Hombre, 1991.

BUTLER, Judith. Problemas de gênero. Feminismo e subversão da identidade. Rio de Janeiro: Civilização Brasileira, 2003.

CASTELLS, Manuel. A sociedade em rede. São Paulo: Paz e Terra, 1999. (A era da informação: economia, sociedade e cultura, v. 1).

O poder da identidade. Rio de Janeiro: Paz e Terra, 2000. v. 2.

. O fim do milênio e a crise de identidade. São Paulo: Paz e Terra, 2001. v. 3.

JOHNSON, Allan G. The Gender Knot. Unraveling Our Patriarchal Legacy. Filadélfia: Temple University Press, 1997.

LAURETIS, Teresa de. Technologies of Gender. Bloomington: Indiana University Press, 1987.

PATEMAN, Carole. O contrato sexual. Rio de Janeiro: Paz e Terra, 1993.

PEREIRA, Luiz. Trabalho e desenvolvimento no Brasil. São Paulo: Difusão Europeia do Livro, 1965.

SAFFIOTI, Heleieth. A mulher na sociedade de classes: mito e realidade. 1967. Tese (Livre-Docência em Sociologia) Universidade Estadual Paulista "Júlio de Mesquita Filho" (UNESP).

A mulher na sociedade de classes: mito e realidade. São Paulo: Livraria 4 Artes Editora, 1969. A segunda e a terceira edições foram publicadas em 1976 e 1979 pela Editora Vozes.

"Rearticulando gênero e classe social". In: COSTA, Albertina de Oliveira; BRUSCHINI, Cristina (Orgs.). Uma questão de gênero. Rio de Janeiro: Rosa dos Tempos; São Paulo: Fundação Carlos Chagas, 1992. p. 183-215.

. "Já se mete a colher em briga de marido e mulher". São Paulo em Perspectiva, v. 13, n. 4, p. 82-91, out./dez. 1999.

SAFFIOTI, Heleieth; ALMEIDA, Suely Souza de. Violência de gênero: poder e impotência. Rio de Janeiro: Revinter, 1995. 